\title{
Feeding and reproductive performance of the harpacticoid Tisbe carolinensis (Copepoda, Crustacea) in four algal cultures*
}

\author{
Wen Yuh Lee, X. K. Zhang, C. Van Baalen \& C. R. Arnold \\ University of Texas, Marine Science Institute, Port Aransas, Texas 78373, USA
}

\begin{abstract}
The functional relation between the harpacticoid copepod Tisbe carolinensis and 4 algal strains was examined in the laboratory. $T$. carolinensis reared either in suspensions of the green alga Chlorella autotrophica (Strain 580) or the 2 blue-green algae Agmenellum quadruplicatum (Strain PR6) and Anabaena sp. (Strain CA) showed marked differential mortalities between sexes, and had fecal production rates of $<0.2$ ind $^{-1} \mathrm{~h}^{-1}$. $T$. carolinensis in these algal cultures produced smaller numbers of brood and fewer viable nauplii than those exposed to the pennate diatom Cylindrotheca sp. (Strain N1) or a mixed diet of all 4 algae. $T$ carolinensis fed actively on Strain N-1 and on the mixture, and fecal pellet production rates averaged $>1.2 \mathrm{ind}^{-1} \mathrm{~h}^{-1}$ Under laboratory conditions $\left(30 \%, 24^{\circ} \mathrm{C}\right)$ with Strain $\mathrm{N}$-1, interclutch interval was estimated to be 4 to $4.5 \mathrm{~d}$, of which 24 to $33 \mathrm{~h}$ was required for oviposition and $3 \mathrm{~d}$ for embryonic development. Successful feeding and reproduction on Strain N-1 and on algal mixture may be associated with larger particle size and somewhat higher nutritional value (i.e. protein and lipid content) of the diatom. This study emphasizes the importance to the copepods of algal type, cell size, and algal protein, carbohydrate, and lipid content, and suggests how these factors may combine to affect $T$. carolinensis population in the field via their effects initially on feeding activity and survival rate, and subsequently on egg production and development.
\end{abstract}

\section{INTRODUCTION}

Benthic harpacticoids are important components of the phytal community (Hicks 1980a,b) and may comprise up to $60 \%$ of meiobenthic organisms (Hicks 1977). They have been reported to be food resources for juvenile fish in nature (Roland 1978, Dethier 1980 , Coull \& Wells 1983) and have also been mass cultured for hatchery purposes (Fujita 1973, Fukusho et al. 1977. Kahan et al. 1982). Yet, information on their food sources in the field and on how different algal species affect their feeding patterns and reproductive persistence is still not well established. Results from laboratory studies generally indicate that benthic harpacticoids are able to ingest a wide variety of diets, namely algae (McIntyre 1969, Harris 1977, Roman 1978), bacteria (Brown \& Sibert 1977, Rieper 1978, Vanden Berghe \& Bergmans 1981) and detritus (Heinle et al. 1977, Ivester \& Coull 1977, Meyer-Reil \& Faubel

- University of Texas Marine Science Institute Contribution No. 658

(c) Inter-Research/Printed in F. R. Germany
1980). In spite of this broad dietary spectrum, most harpacticoids are believed to be feeding specialists rather than generalists (Lee et al. 1976, Rieper 1978, Berghe \& Bergmans 1981, Hicks \& Coull 1983).

The present work examines the functional relation of feeding rates and reproductive response between a phytal harpacticoid (Tisbe carolinensis VolkmannRocco) and 4 potential food sources; a green alga, a pennate diatom, and 2 blue-green algae (cyanobacteria). Feeding rates were expressed as fecal pellet production rates. Reproductive performance was gauged by egg production rates, embryonic development time, and total nauplii released during the experiment. Changes in these biological parameters were then related to cell size, and protein, carbohydrate, and lipid composition of the algae.

\section{MATERIALS AND METHODS}

Harpacticoids. Tisbe carolinensis were collected from Ulva fasciata thalli growing on the rock jetties 
near the University of Texas Port Aransas Marine Laboratory. They were placed in dishes $(20 \mathrm{~cm}$ $\times 7.5 \mathrm{~cm}$ ) containing $1.2 \mathrm{l}$ of $0.45 \mu \mathrm{m}$ filtered seawater $(30 \%)$, and fed with dry $U$. fasciata fragments. The stock cultures were kept at room temperature $\left(24^{\circ}\right.$ $\pm 1.5 \mathrm{C}^{\circ}$ ).

Algal diets. Four algae were employed in this study: a pennate diatom Cylindrotheca $\mathrm{sp}$. (Strain N-1), a green alga Chlorella autotrophica (Strain 580), and 2 blue-green algae, the coccoid form Agmenellum quadruplicatum (Strain PR-6), and Anabaena sp. (Strain CA). They were grown in $20 \mathrm{ml}$ ASP-2 medium (Van Baalen 1962) in $22 \times 175 \mathrm{~mm}$ Pyrex tubes. For the diatom, the ASP-2 medium also contained $\mathrm{NaSiO}_{3} \cdot 5 \mathrm{H}_{2} \mathrm{O}\left(250 \mathrm{mg} \mathrm{l}^{-1}\right), \mathrm{NH}_{4} \mathrm{Cl}\left(50 \mathrm{mg} \mathrm{l^{-1 }}\right)$ and vitamin $B_{12}\left(8 \mu \mathrm{g} \mathrm{l}^{-1}\right)$. For Strain 580, vitamin $B_{12}$ $\left(8 \mu \mathrm{g} \mathrm{l}^{-1}\right)$ and thiamine $\left(1 \mathrm{mg} \mathrm{l}^{-1}\right)$ were added to the medium. For Strain PR-6, the ASP-2 medium contained vitamin $B_{12}\left(8 \mu \mathrm{g} \mathrm{l}^{-1}\right)$ only. Axenic cultures of the 4 algae were grown in a constant temperature water bath $\left(30^{\circ} \mathrm{C}\right)$ under a continuous light intensity of $90 \mu \mathrm{E}$ $\mathrm{m}^{-2} \mathrm{~s}^{-1}$ (F40 CWX fluorescent lamps), with $1 \% \mathrm{CO}_{2}$ in-air continuously bubbled through the cultures. Algal cells were harvested during logarithmic growth and used either for determinations of carbohydrate, protein and lipid content or for the feeding experiment with the harpacticoids.

Feeding and reproduction experiments. Ovigerous females and adult males of Tisbe carolinensis were selected from the stock cultures and separated into male-female pairs. Before the experiments, the copepods were transferred through 4 baths of $0.45 \mu \mathrm{m}$ filtered seawater to minimize contamination with bacteria and Ulva fasciata fragments. Then each malefemale pair was placed in a plastic Petri dish $(35 \mathrm{~mm}$ $\times 10 \mathrm{~mm}$ ) containing $5 \mathrm{ml}$ of seawater $(30 \%)$ and $0.5 \mathrm{ml}$ of one of the prepared algal diets.

Algal diets were all prepared from the 4 axenic cultures. The algal cultures were first adjusted to an optical density (OD) of 0.22 (Lumetron colorimeter model $402 \mathrm{E}$ ). Then $0.5 \mathrm{ml}$ of this preparation was added to each of the experimental dishes. In addition to the 4 diets, a control and a mixed diet were also provided. The control contained only filtered seawater, whereas the mixed diet included $0.125 \mathrm{ml}$ each of the 4 prepared algal diets. Cell numbers at $O D=0.22$ varied with algal species and were estimated to be about $1 \times 10^{5}$ cells $\mathrm{ml}^{-1}$ for the diatom Strain N-1, $2 \times 10^{5}$ cells $\mathrm{ml}^{-1}$ for the blue-green alga Strain CA, $1 \times 10^{7}$ cells $\mathrm{ml}^{-1}$ for the blue-green alga Strain PR-6 and $1 \times 10^{6}$ cells ml-1 for the green alga Strain 580. At $\mathrm{OD}=0.22$ cell dry weights were $56,118,44$ and $47 \mu \mathrm{g}$ $\mathrm{ml}^{-1}$ respectively.

Five replicates were run for each food type, making a total of 30 experimental dishes. All dishes were covered with lids to reduce evaporation and were kept at room temperature $\left(24^{\circ} \mathrm{C} \pm 1.5 \mathrm{C}^{\circ}\right)$. The copepods were transferred to new algal medium every other day until experiments were terminated (Day 15). Algal media were always clear in Petri dishes and we noticed no significant bacterial contamination during the experiments.

Harpacticoid feeding and reproductive activities during the experiments were examined and used as measures for the determination of food quality. Feeding activity was estimated by the quantity of fecal pellets produced during a $6 \mathrm{~h}$ interval rather than by the amounts of food ingested. Counting of fecal pellets in each dish was made at Days 1, 3, 5, and 7, after the algal media were replaced. For reproductive performance, records were kept on adult mortality, daily egg development, egg-sac production and number of viable nauplii released. Hatched nauplii were also removed daily from the dishes to avoid possible predation by the adults.

Although it has been shown that a single mating may support the entire egg production of a female harpacticoid, dead males were replaced to insure opportunities for a necessary subsequent mating. In this case, longevity and survival counts were still referred to the original male employed at the beginning of the experiment.

Biochemical components of algal diets. Carbohydrate and lipid were determined by photometric methods of Kochert (1978a,b), using glucose and palmitic acid as standards, respectively, while protein was measured with the Folin phenol reagent using bovine serum albumen as a standard (Lowry et al. 1951).

Briefly, algal cells were collected by centrifuging $20 \mathrm{ml}$ of algal culture with $\mathrm{OD}$ ranging from 0.37 to 0.70 . The pellets were first treated with $0.2 \mathrm{~N} \mathrm{HClO}_{4}$ and then extracted with chloroform-methanol mixture $(2: 1 \mathrm{v} / \mathrm{v})$ to obtain the lipid component. Finally, the acid-extracted, lipid-free pellets were treated with $2 \mathrm{ml} \mathrm{NaOH}(2 \mathrm{~N})$ at $95^{\circ} \mathrm{C}$ for $10 \mathrm{~min}$. From this sample, aliquots were drawn for protein assay, and the remainder was then assayed for carbohydrate using the phenol-sulfuric acid method. Data are presented as percentage of algal dry weights, corrected for ash.

\section{RESULTS}

\section{Algal food}

The 4 algal diets varied in both their cell size and morphology (Table 1). The pennate diatom was the largest, with cell size ranging from $3 \times 10 \mu \mathrm{m}$ to $4 \times 15 \mu \mathrm{m}$, and the coccoid blue-green alga PR- 6 was the smallest, with cell diameter $<2 \mu \mathrm{m}$. The cells of 
Table 1. Characteristics of the 4 algal diets fed to Tisbe carolinensis

\begin{tabular}{|c|c|c|c|c|}
\hline & \multicolumn{4}{|c|}{ Strain } \\
\hline & PR-6 & $\mathrm{CA}$ & 580 & $N-1$ \\
\hline Type & Blue-green & Blue-green & Green & Diatom \\
\hline Typical habitat & Tidal flats & Tidal flats & Estuaries & Littoral zone \\
\hline Form & Unicellular & Chained & Unicellular & Pennate \\
\hline Cell size $(\mu \mathrm{m})$ & 1.5 to 2 & $\begin{array}{c}4 \text { to } 6 \\
\text { (Heterocysts } 6 \text { to } 7 \text { ) }\end{array}$ & 3 to 4 & 3 to $4 \times 10$ to $15^{\circ}$ \\
\hline - Diameter $\times$ length & & & & \\
\hline
\end{tabular}

the blue-green alga CA were also small but formed chains some 10 to 20 cells long. Heterocysts (thickwalled cells specialized for nitrogen-fixation), making up 10 to $12 \%$ of the filament, were 6 to $7 \mu \mathrm{m}$ in diameter. In terms of dry weight per unit volume fed to Tisbe carolinensis, CA ranked first $\left(118 \mu \mathrm{g} \mathrm{ml} \mathrm{ml}^{-1}\right)$ followed by N-1, 580 and PR- 6 .

As expected, protein was the major component of the 4 algae and averaged about $50 \%$ of dry weight. A ttest was performed comparing the 2 highest protein contents in the algal Strains PR- 6 and $N-1$. The result was statistically significant $(t=5.31$, $d f=6, p<0.05$ ), indicating that percentage protein in $\mathrm{N}-1(58 \%)$ was significantly higher than that in PR-6 $(50 \%)$. Carbohydrate was the second major constituent in Strains PR-6, CA and 580, but ranked third in the diatom. Average percentage dry weights of carbohydrate in CA, 580, and PR-6, were 43, 41 and $40 \%$ respectively, but in N-1 only about $12 \%$. Lipid level ranged from 5 to $24 \%$ of dry weight, with the lowest value recorded in the blue-green alga PR-6, and the highest in the diatom N-1 (Table 2).

\section{Effects of diets on copepods}

Survival, feeding activity and production of Tisbe carolinensis nauplii in the 5 algal diets were deter- mined and compared. The copepods survived best in the mixed diet in which $100 \%$ of both males and females remained alive during the $15 \mathrm{~d}$ experiment (Table 3 ). The worst survival $(20 \%)$ was recorded in the green alga 580, compared to $0 \%$ in the controls. In the other 3 diets, mortality rates were intermediate, averaging $\geq 50 \%$. A marked differential mortality between the sexes was also observed among the different diets. In PR-6, CA and 580, male copepods generally survived better than females, while the reverse was the case for those reared in $\mathrm{N}-1$. Without algal food, average longevity was $8 \mathrm{~d}$ for males and $5 \mathrm{~d}$ for females.

Feeding activity of copepods in the presence of Strains PR-6, CA and 580 was not apparent. In many cases we found dishes containing no fecal pellets during the experiment. Average fecal pellet production rates in these algae were about 0.2 pair $^{-1} \mathrm{~h}^{-1}$. On the other hand, copepods with $\mathrm{N}-1$ and mixed diet were found actively feeding and pellet production rates were estimated to exceed 2 pair $^{-1} \mathrm{~h}^{-1}$. An independent group t-test was carried out to compare the feeding activity of the 2 groups, in N-1 and in mixed diet. The calculated $\mathrm{t}$ was not statistically significant ( $t=0.92, \quad d f=38, p>0.05)$, suggesting that mean feeding rates in $\mathrm{N}-1$ did not differ significantly from those in the mixed diet.

Table 2. Major chemical composition of the 4 algal diets, expressed as percentage of dry weight $\pm 1 \mathrm{SD}$. n: number of observations

\begin{tabular}{|c|c|c|c|}
\hline $\begin{array}{l}\text { Species } \\
\text { (Strain) }\end{array}$ & Protein & Carbohydrate & Lipid \\
\hline $\begin{array}{l}\text { Agmenellum quadruplicatum } \\
\qquad(\mathrm{PR}-6)\end{array}$ & $\begin{array}{l}50.3 \pm 1.6 \\
\quad(\mathrm{n}=4)\end{array}$ & $\begin{array}{l}39.5 \pm 1.8 \\
(\mathrm{n}=2)\end{array}$ & $\begin{array}{l}5.4 \pm 0.6 \\
(\mathrm{n}=2)\end{array}$ \\
\hline $\begin{array}{c}\text { Anabaena sp } \\
\text { (CA) }\end{array}$ & $\begin{array}{l}49.6 \pm 2.0 \\
\quad(n=4)\end{array}$ & $\begin{array}{c}43.1 \pm 2.5 \\
(n=2)\end{array}$ & $\begin{array}{l}5.5 \pm 1.6 \\
(\mathbf{n}=2)\end{array}$ \\
\hline $\begin{array}{l}\text { Chlorella autotrophica } \\
\qquad(580)\end{array}$ & $\begin{array}{l}48.5 \pm 6.8 \\
(\mathrm{n}=2)\end{array}$ & $\begin{array}{c}40.6 \pm 0.1 \\
(n=2)\end{array}$ & $\begin{array}{c}13.5 \pm 2.9 \\
(n=2)\end{array}$ \\
\hline $\begin{array}{l}\text { Cylindrotheca sp. } \\
\qquad(\mathrm{N}-1)\end{array}$ & $\begin{array}{l}57.6 \pm 2.2 \\
(\mathrm{n}=4)\end{array}$ & $\begin{array}{l}12.2 \pm 2.2 \\
(\mathrm{n}=4)\end{array}$ & $\begin{array}{c}24.3 \pm 4.2 \\
(\mathrm{n}=4)\end{array}$ \\
\hline
\end{tabular}


Table 3. Tisbe carolinensis. Survival and feeding activity in 5 algal diets and control

\begin{tabular}{|c|c|c|c|c|c|}
\hline \multirow[t]{2}{*}{ Diet } & \multicolumn{2}{|c|}{$\begin{array}{c}\text { Survival } \\
\%\end{array}$} & \multicolumn{2}{|c|}{$\begin{array}{l}\text { Longevity } \\
\text { (d) }\end{array}$} & \multirow{2}{*}{$\begin{array}{l}\text { Mean fecal } \\
\text { production } \\
\pm 1 \mathrm{SD} \\
\text { No. pair } \\
\mathrm{h}^{-1}\end{array}$} \\
\hline & Male & Female & Male & Female & \\
\hline Control & 0 & 0 & $8 \pm 2.9\left(5^{\circ}\right)$ & $4.8 \pm 2.2(5)$ & $0.1 \pm 0.2(20)$ \\
\hline PR-6 & 80 & 20 & $-\cdots$ & - & $0.2 \pm 0.1(20)$ \\
\hline $\mathrm{CA}$ & 100 & 40 & - & - & $0.2 \pm 0.1(20)$ \\
\hline 580 & 40 & 0 & - & $9.2 \pm 3.4(5)$ & $0.2 \pm 0.1(19)$ \\
\hline $\mathrm{N}-1$ & 60 & 80 & - & - & $2.7 \pm 1.1(20)$ \\
\hline Mixture & 100 & 100 & - & - & $2.4 \pm 0.7(20)$ \\
\hline \multicolumn{6}{|c|}{ - Number of observations } \\
\hline
\end{tabular}

Two size classes of fecal pellets had been noticed during the feeding experiment. The larger pellets were estimated to be $33.4 \times 140 \mu \mathrm{m}(\mathrm{n}=20)$ and the smaller ones were about half the size. This difference in pellet size is believed to be associated with the sexual dimorphism of Tisbe carolinensis, in which adult fenales were almost twice as large $(0.60$ to $0.85 \mathrm{~mm})$ as adult males $(0.40$ to $0.45 \mathrm{~mm}$ ). If experiments are carefully designed in future studies, differential feeding behavior between sexes should be detectable.

Reproductive performance during the experiment was estimated for copepods feeding on the 5 algal diets (Table 4). A 1-way ANOVA was performed comparing mean brood production of the 6 groups (including controls). The derived $F$ was statistically significant $(F=15.08$, df $=5,24, p<0.05)$, indicating that there was a relation between reproduction and algal diet. The strength of the relation, as expressed by etasquared, was strong (0.76). A Duncan's multiple range test further divided the 6 groups into 2 homogeneous subsets. One subset included copepods fed on Strains PR-6, 580, CA and the control, while the other encompassed copepods provided with $\mathrm{N}-1$ and the mixed diet. Mean brood production by the latter groups (2.6 to 3.0 broods) was significantly higher than that by the former groups ( 0 to 0.4 broods). Within subsets, the means were not significantly different from each other.

Egg-sac formation and hatching times showed similar trends to those observed for the mean brood production. Oviposition for copepods in the diatom N-1 and in the algal mixture took 24 to $33 \mathrm{~h}$ and these eggs, on average, hatched $3 \mathrm{~d}$ later. Accordingly, the estimated time interval between production of 2 egg sacs was 4 to $4.5 \mathrm{~d}$. On the other hand, copepods in the control or with Strains PR-6, CA and 580 produced either few egg sacs or none, which made the determination of production intervals difficult or impractical.

The maximum number of offspring (635) produced during the experiment was obtained with copepods fed the diatom N-1, while the least (46) was with those fed PR-6. Although the mixed algal diet was seemingly nutritionally equivalent to Strain $\mathrm{N}-1$ alone, as to its effects on brood production, egg-sac formation $(\mathrm{t}=1.72, \mathrm{df}=26, \mathrm{p}>0.05)$ and embryonic development $(\mathrm{t}=1.41, \mathrm{df}=22, \mathrm{p}>0.05)$, the total number of nauplii released in the mixture was much fewer (378).

Table 4. Tisbe carolinensis. Reproductive performance estimated for 5 algal diets and control over $15 \mathrm{~d}$

\begin{tabular}{|c|c|c|c|c|c|}
\hline Algal diet & $\begin{array}{c}\text { Mean brood } \\
\text { production } \\
\pm 1 \mathrm{SD} \\
\text { No. pair }\end{array}$ & $\begin{array}{c}\text { Mean } \\
\text { naupliar } \\
\text { production } \\
\text { No. brood }\end{array}$ & $\begin{array}{c}\text { Total } \\
\text { naupliar } \\
\text { production }\end{array}$ & $\begin{array}{c}\text { Egg-sac } \\
\text { formation } \\
\text { time } \frac{ \pm}{h} 1 S D\end{array}$ & $\begin{array}{c}\text { Embryonic } \\
\text { development } \\
\text { time } \pm 1 \mathrm{SD} \\
\mathrm{h}\end{array}$ \\
\hline Control & $0\left(5^{\circ}\right)$ & 24.2 & 121 & $-\cdot \cdot$ & - \\
\hline PR-6 & $0(5)$ & 9.2 & 46 & - & - \\
\hline $\mathrm{CA}$ & $0.4 \pm 0.6(5)$ & 26.1 & 183 & $48 \pm 34(2)$ & $96 \pm 34(2)$ \\
\hline 580 & $0.2 \pm 0.5(5)$ & 8.0 & 48 & $96 \quad(1)$ & 72 \\
\hline N-1 & $3.0 \pm 1.7(5)$ & 35.9 & 635 & $24 \pm 0(15)$ & $68 \pm 20(12)$ \\
\hline Mixture & $2.6 \pm 0.6(5)$ & 23.6 & 378 & $33 \pm 21(13)$ & $77 \pm 10(12)$ \\
\hline \multicolumn{6}{|c|}{$\begin{array}{l}\text { - Number of observations } \\
\text { - No egg sacs produced during experiment }\end{array}$} \\
\hline
\end{tabular}


Accordingly, copepods reared on the mixed diet had smaller brood size, averaging about 12 nauplii fewer per brood (Table 4).

\section{DISCUSSION}

A combination of different algae has been shown to be a better diet than monoxenic algal cultures, and it is assumed that a mixed diet generally provides a more balanced nutrition, including vitamins, minerals and trace elements necessary for animals' survival, growth and reproduction (Provasoli et al. 1959, Harris 1977. Zurlini et al. 1978). Results from the present study support this assumption. However, it also appeared that Tisbe carolinensis performed equally well or even better when it was provided exclusively with the diatom Strain N-1. Since no experiments were carried out to compare the food value of the mixed diet with and without N-1 diatom, the nutritional role of this diatom in the mixture cannot be determined at present.

Microscopic examinations of the mouthparts of Tisbe carolinensis showed that they were more likely to be surface browsers rather than suspension feeders due to absence of heavy setose in their maxillae and maxillipeds. The diatom $\mathrm{N}-1$ with its larger cell size was thus much preferred to the smaller strains (PR-6, CA or 580 ) and was consumed at higher rates.

Sexual dimorphism in size has been noted for many harpacticoids (Lang 1948, Volkmann-Rocco 1972. Hicks 1980b). Adult females tend to be larger than males. Male Tisbe carolinensis average about 50 to $60 \%$ of the female length (from rostrum to caudal rami). The ecological significance of sexual dimorphism could be manifold, such as for sex recognition or for reduction of intraspecific competition for food sources. The size differences in feeding apparatus and hence the divergence in food choice between males and females may therefore account for the differential sex mortality encountered in the 3 algal diets (PR-6, CA and 580). Under the stress of small food particles, the smaller adult males may benefit because their smaller feeding appendages allow them to utilize the food more efficiently than the larger females.

The association between blue-green algae and harpacticoids in the near-shore benthic marine environment is less well-defined when compared with its pelagic counterpart of Trichodesmium sp. and $\mathrm{Ma}$ crosetella gracilis (Bjornberg 1965, Calef \& Grice 1966 , Roman 1978). Blue-green algae and some green algae are generally believed to be poorly utilized by herbivorous copepods. With Strains PR-6, CA and 580, Tisbe carolinensis produced fewer broods, smaller clutch size and fewer viable nauplii than copepods with Strain N-1 or the mixture. Compared to controls, harpacticoids in PR-6 and 580 also had lower naupliar production. Since the experiments started with gravid females, copepods reared in Strains PR- 6 and 580 were expected to release at least as many nauplii as those in the control, even though the 2 algae were not ingested at all. These algae may, therefore, contain some inhibitors for $T$. carolinensis. Additionally, we observed during the experiment that naupliar development was arrested in some eggs and these eggs eventually decayed. Dropping egg mass from females had also been occasionally found in dishes of 2 diets (PR-6 and 580), and this was in contrast to the normal developmental process in which the egg case was always retained until eggs hatched as Stage 1 nauplii. Harris (1977) noted a similar phenomenon for the harpacticoid Scottolana canadensis but considered it to be a response to a stress due to food deprivation (Hicks \& Coull 1983).

The interval between consecutive egg sacs was estimated to be 4 to $4.5 \mathrm{~d}$ for copepods provided with $\mathrm{N}-1$ or the mixed diet. The interval included about 1 to $1.5 \mathrm{~d}$ for oviposition and $3 \mathrm{~d}$ for embryonic development. We have found no other studies dealing with this species and direct comparisons of egg production between related species were also difficult because experimental conditions such as diets and water temperature were different. However, more rapid production rates have been documented for littoral harpacticoids such as Tigriopus brevicornis and $T$. japonicus. The former species, when provided with natural concentrations of particulate matter, was estimated to have an interval of $3 d$, and a new egg sac was formed as soon as the previous one had hatched (Harris 1973). The latter species was reported to attain 11 broods within $25 \mathrm{~d}$ when held at $23^{\circ} \mathrm{C}$ (Takano 1971). Both food type and concentration were not specified.

In the present study, feeding activity is expressed as fecal pellet production. It is understood that the measurements illustrate only fecal passage and may not serve as evidence for digestion. Similarly, the protein analyses performed on the algal cells reflect only the total amount of protein, and do not discriminate between digestibilities or differences in essential amino acid content. Nevertheless, results on feeding and reproduction do imply that diatom $\mathrm{N}-1$ is a better diet, with regard to both its nutrition and digestibility, than Strains PR-6, CA or 580.

Harpacticoids are widely distributed in coastal waters and particularly abundant in phytal habitats (Moore 1973, Hicks 1980b). In situ, they were reported to feed on algae and settled organic particles and in turn, they were preyed upon by blennioid and gobiid fish (Zander \& Heymer 1977, Roland 1978, Coull \& Wells 1983, Huh 1983). The actual functional relation between the harpacticoids and algal food sources, 
however, still remains to be established (Coull \& Bell 1979). The 4 algal strains employed in this study are common and may be seasonally abundant in coastal waters (Van Baalen 1962, Reimann \& Lewin 1964). Hence, they may be encountered in places where Tisbe spp. occur. Results from the present study suggest that when small sized blue-green algae such as CA and PR-6 are dominant in the algal assemblages, it may lead to changes in the copepod population via initial lowering of feeding activity, female survival rates, and subsequent arrest of egg development and production. In conclusion, the present study documents the importance of the 3 factors - namely algal type, its nutritional content and cell size - and their effects as a whole on Tisbe carolinensis feeding and reproductive activity.

Acknowledgements. We thank Dr. B. Volkmann-Rocco, Instituto di Biologia del Mare, Venice, Italy, for assistance in identification of the harpacticoid Tisbe carolinensis, and Dr. W. Pulich, Jr. for critically reading this manuscript. Technical assistance provided by R. O'Donnell is greatly appreciated. This work was supported in part by the Caesar Kleberg Foundation for Wildlife Conservation.

\section{LITERATURE CITED}

Bjornberg, T, K. (1965). Observations on the development and the biology of the Miracidae Dana (Copepoda, Crustacea) Bull. mar. Sci. 15: 512-520

Brown, T. J., Sibert, J. R. (1977). Food of some benthic harpacticoid copepods. J. Fish. Res. Bd Can. 34: 1028-1031

Calef, G. W., Grice, G. D. (1966). Relationship between the blue-green alga Trichodesmium thiebautii and the copepod Macrosetella gracilis in the plankton off northeastern South America. Ecology 47: 855-856

Coull, B. C., Bell, S. S. (1979). Perspectives of marine meiofaunal ecology. In: Livingston, R. J. (ed.) Ecological processes in coastal and marine systems. Plenum Press, New York, p. 189-216

Coull, B. C., Wells, J. B. J. (1983). Refuges from fish predation: experiments with phytal meiofauna from the New Zealand rocky intertidal. Ecology 64: 1599-1609

Dethier, M. N. (1980). Tidepools as refuges: predation and the limits of the harpacticoid copepod Tigriopus californicus (Baker). J. exp. mar. Biol. Ecol. 42: 99-111

Fujita, S. (1973). Importance of zooplankton mass culture in producing marine fish seed for fish farming. Bull. Plankton Soc. Japan 20: 49-53

Fukusho, K., Hara, O., Iwamoto, H., Kitajima, C. (1977). Mass production of the copepod Tigriopus japonicus, in combination with the rotifer, Brachionus plicatilis, feeding baking yeast and using large-scale outdoor tanks (AprilAugust). Bull. Nagasaki Pref. Inst. Fish. 3: 33-40

Harris, R. P. (1973). Feeding, growth, reproduction and nitrogen utilization by the harpacticoid copepod, Tigriopus brevicornis. J. mar. biol. Ass. U.K. 53: 785-800

Harris, R. P. (1977). Some aspects of the biology of the harpacticoid copepod, Scottolana canadensis (Willey), maintained in laboratory culture. Chesapeake Sci. 18: 245-253

Heinle, D. R., Harris, R. P., Ustach, J. F., Flemer, D. A. (1977).
Detritus as food for estuarine copepods. Mar. Biol. 40: 341-353

Hicks, G. R. F. (1977). Species composition and zoogeography of marine phytal harpacticoid copepods from Cook Strait. and their contributions to total phytal meiofauna. N.Z. Jl mar. Freshwat. Res. 11: 441-469

Hicks, G. R. F. (1980a). Seasonal and geographic adaptation to temperature and salinity in the harpacticoid copepod Zaus spinatus spinatus Goodsir. J. exp. mar. Biol. Ecol. 42: 253-266

Hicks, G. R. F. (1980b). Structure of phytal harpacticoid copepod assemblages and the influence of habitat complexity and turbidity. J. exp. mar. Biol. Ecol. 44: 157-192

Hicks, G. R. F., Coull, B. C. (1983). The ecology of marine meiobenthic harpacticoid copepods. Oceanogr. mar. Biol. A. Rev. 21: 67-175

Huh, S. H. (1983). Seasonal variations and trophic relationships among concentrated populations of small fishes in seagrass meadows. Ph. D. thesis, Univ. of Texas, Austin

Ivester, M. S., Coull, B. C. (1977). Niche fractionation studies of two sympatric species of Enhydrosoma (Copepoda, Harpacticoida). Mikrofauna Meeresboden 61: 137-151

Kahan, D., Uhlig, G., Schwenzer, D., Horowitz, L. (1982). A simple method for cultivating harpacticoid copepods and offering them to fish larvae. Aquaculture 26: 303-310

Kochert, G. (1978a). Carbohydrate determination by the phenol-sulfuric acid method. In: Hellebust, J. A., Craigie, J. S. (ed.) Handbook of phycological methods - physiological and biochemical methods. Cambridge University Press, London, p. 96-97

Kochert, G. (1978b). Quantitation of the macromolecular components of microalgae. In: Hellebust, J. A., Craigie, J. S. (ed.) Handbook of phycological methods - physiological and biochemical methods. Cambridge University Press, London, p. 189-195

Lang, K. (1948). Monographie der Harpacticiden. Hakan Ohlssons Boktryckeri, Lund

Lee, J. J., Tietjen, J. H., Garrison, J. R. (1976). Seasonal switching in the nutritional requirements of Nitocra typica, a harpacticoid copepod from salt marsh aufwuchs communities. Trans. Am. microsc. Soc. 95: 628-637

Lowry, O. H., Rosebrough, N. J., Farr, A. L., Randall, R. J. (1951). Protein measurement with the Folin phenol reagent. J. biol. Chem. 193: 265-275

McIntyre, A. D. (1969). Ecology of marine meiobenthos. Biol. Rev. 44: 245-290

Meyer-Reil, L. A., Faubel, A. (1980). Uptake of organic matter by meiofauna organisms and interrelationships with bacteria. Mar. Ecol. Prog. Ser. 3: 251-256

Moore, P. G. (1973). The kelp fauna of northeast Britain. II. Multivariate classification: turbidity as an ecological factor. J. exp. mar. Biol. Ecol. 13: 127-163

Provasoli, L., Shiriashi, K., Lance, J. R. (1959). Nutritional idiosyncracies of Artemia and Tigriopus in monoxenic culture. Ann. N.Y. Acad. Sci. 77: 250-261

Reimann, B. E. F., Lewin, J. C. (1964). The diatom genus Cylindrotheca Rabenhorst (with a reconsideration of Nitzschia closterium). J. R. microsc. Soc. 83: 283-296

Rieper, M. (1978). Bacteria as food for marine harpacticoid copepods. Mar. Biol. 45: 337-345

Roland, W. (1978). Feeding behaviour of the kelp clingfish Rimicola muscarum residing on the kelp Macrocystis integrifolia. Can. J. Zool. 56: 711-712

Roman, M. R. (1978). Ingestion of the blue-green alga Trichodesmium by the harpacticoid copepod, Macrosetella gracilis. Limnol. Oceanogr 23: 1245-1248

Takano, H. (1971). Breeding experiments of a marine littoral 
Tigriopus japonicus Mori. Bull. Tokai reg. Fish. Res. Lab 64: 71-80

Van Baalen, C. (1962). Studies on marine blue-green algae. Botanica mar. 4: 129-139

Vanden Berghe, W., Bergmans, M. (1981). Differential food preferences in three co-occuring species of Tisbe (Capepoda, Harpacticoida). Mar. Ecol. Prog. Ser. 4: 213-219

Volkmann-Rocco, B. (1972). Species of Tisbe (Copepoda, Harpacticoida) from Beaufort, North Carolina. Archo. Oceanogr. Limnol. 17: 223-258
Zander, C. D., Heymer, A. (1977). Analysis of ecological equivalents among littoral fish. In: Keegan, B. F., Oceidigh, P. O., Boaden, P. J. S. (ed.) Biology of benthic organisms, Proc. 11th Europ. Mar. Biol. Symp., Pergamon Press, Oxford, p. 621-630

Zurlini, G., Ferrari, I., Nassogne, A. (1978). Reproduction and growth of Euterpina acutifrons (Copepoda: Harpacticoida) under experimental conditions. Mar. Biol. 46: 59-64

This paper was submitted to the editor; it was accepted for printing on May 9, 1985 